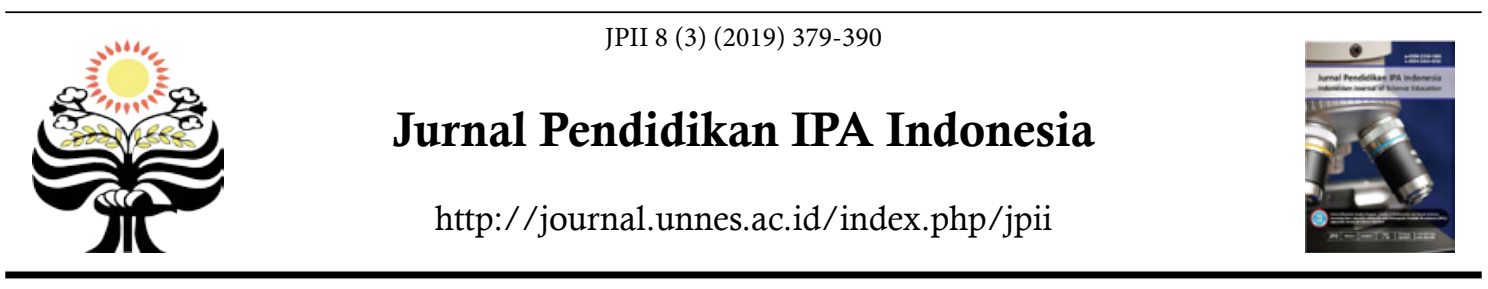

\title{
EXPLORING THE PROSPECTIVE TEACHERS' CRITICAL THINKING AND CRITICAL ANALYSIS SKILLS
}

\author{
H. Fitriani ${ }^{1}$, M. Asy'ari*2, S. Zubaidah ${ }^{3}$, S. Mahanal ${ }^{4}$ \\ ${ }^{1,2}$ Institut Keguruan dan Ilmu Pendidikan (IKIP) Mataram, Indonesia \\ ${ }^{3,4}$ Biology Department, Universitas Negeri Malang, Indonesia
}

DOI: 10.15294/jpii.v8i3.19434

Accepted: May $9^{\text {th }}, 2019$. Approved: September 28 $8^{\text {th }}, 2019$. Published: September $30^{\text {th }}, 2019$

\begin{abstract}
This study aimed to explore the prospective teachers' critical thinking and critical analysis skills based on gender. This is a descriptive quantitative study with survey methods. The research samples were 50 males and 50 females who take the anatomy and plant development courses selected using purposive random sampling. The data of prospective teachers' critical thinking and critical analysis skills were collected using the instrument developed that was validated by two experts and tested on 20 biology education students. The data of prospective teachers' critical thinking and critical analysis skills were analyzed descriptively and statistically using a software (IBM SPSS Statistic 23). The results of the study show that (1) the prospective teachers' critical thinking and critical analysis skills as underdeveloped; (2) critical thinking skills differ in the components of interpretation, explanation, and self-regulation; (3) critical analysis skills differ on the explanation and interpretations; and (4) there is a positive correlation between prospective teachers' critical thinking and critical analysis skills. Based on the result of the study, serious and planned handling can be done through important learning. The results of this study can be an initial reference and priority determination of lecturers in teaching prospective teachers' critical thinking and critical analysis skills based on gender.
\end{abstract}

(C) 2019 Science Education Study Program FMIPA UNNES Semarang

Keywords: critical thinking skills, critical analysis skills, gender

\section{INTRODUCTION}

Critical thinking skill is still a priority of learning and research in various disciplines. Aliakbari \& Sadeghdaghighi (2011) stated that critical thinking skill is important since they are integrated with everyday life. According to Facione (2007); Ennis (1996), critical thinking greatly influences the success of one's learning and career. In line with those statements, the $21^{\text {st }}$ century learning which really puts it emphasize on student-oriented learning requires innovative thinking skill such as critical thinking

*Correspondence Address

E-mail: muhammadasyari@ikipmataram.ac.id skill (Mishra \& Kereluik, 2011), analysis based on good reasoning (Muhali, 2018) with regard to disposition thinking (Facione, 2007; Ennis, 1996).

Many definitions of critical thinking were proposed by experts such as critical thinking is an art in analyzing and evaluating (Paul \& Elder, 2019) as an effort to improve thinking independence through good judgment and evaluation (Reid, 2006). Critical thinking has long been an approach in learning. (Dewey, 1933) introduces critical thinking as "reflective thinking" which is explained as an active, persistent, thorough consideration of a belief and form of knowledge received in terms of reasons 
that support it and further conclusions that be- information in the form of data, facts, observacome its tendency (Fisher, 2011). Critical thin- tion, experience or other sources that can help king skill as a process according to Ennis (2011) someone solve the problem at hand; (4) concep is reflective and evaluative processes to deter- is in the form of thinking patterns that become mine what funds are believed to do. According a frame of work in thinking and acting; (5) asto Facione (2007) critical thinking is basically sumptions that describe the mind's "baseline", a detailed description of several characteristics (6) points of view in the form of a person's point which include the process of interpretation, of view in reasoning and thinking that involves analysis, evaluation, inference, explanation and a process of interpretation and understanding self-regulation. On the other hand, Ennis (1996) something; (7) interpretation and inference (inprovided the same definition as Hassard \& Dias terpretation and drawing conclusions) which (2013) about the concept of critical thinking in function to understand data and draw concluwhich critical thinking as a reasonable and ref- sions; and (8) implication and consequence in lective thought that focuses on deciding what to the form of readiness to face the implication believe or do.

Critical thinking is an intellectual process that is actively and skillfully conceptualizing, applying, analyzing, synthesizing, and or evaluating information collected, or produced by observing, reflecting, considering, or communicating, as a guide to trust and do (Moore \& Parker, 2009). Specifically, critical thinking is seen as a cognitive process. Common cognitive abilities include the ability to interpret, analyze, evaluate, infer, explain and regulate themselves (Facione, 1990)

If the definition is examined, critical thinking skills consist of 2 (two) importan components that is critical thinking cognitive skills and critical thinking dispositions. Cognitive thinking and critical thinking dispositions have a role in analyzing fairness and solving
problems faced. A good critical thinker should problems faced. A good critical thinker should
not only has critical thinking cognitive skill, but not only has critical thinking cognitive skill, but
also critical thinking dispositions so that the also critical thinking dispositions so that the
contribution of critical thinking as a provider of contribution of critical thinking as a provider of fair analysis in so.

Almost everyone who deals with critical thinking has produced a list of thinking skills that they see as the basis for critical thinking Critical thinking is a skill, thinking responsib-
ly which facilitates good decisions because (1) ly which facilitates good decisions because (1)
it depends on criteria; (2) it is self-correction; it depends on criteria; (2) it is self-correction;
and (3) it is sensitive to context (Lipman (1987). and (3) it is sensitive to context (Lipman (1987). thinking is like a set of conceptual devices by hinking is like a set of conceptual devices by connecting intellectual abilities and strategies that are useful for making reasonable decision Paul \& El tor (2019) explain the of function of critical thinking skils into functions in which each function represents an important part of the quality of thinking and results as a whole such as: (1) questioning at is sue (questioning the problem); (2) purpose; (3) and consequences of thought processes carried

Critical analysis is the ability of student to descibe information into smaller parts so that deeper meaning is obtained through organizing and connecting the parts in the information so that more comprehensive meanin is obtained based on the results of the analysi (Asy' ar will be able to make decisions conrectly (Asy'ari \& Fitriani, 2017). Appropriate decisithe evaluate) (Ennis, 2011). Through these find weaknesses and strengths so that they can produce something new or different from what has already exists. Furthermore, Krathwohl \& Anderson (2009) explained that analyzing is the ability to break things down into smalle parts so that deeper meaning can be obtained Analyzing is the ability to organize and connec meaning. The obility to a more comprehensive meaning. The ability to analyze will end in the process of critical thinking so that someone is Critical analysis requires a logical, critical, solve the problem (Brookhart, 2010). Critical anasis is shown through identification of infe rential relationships between statements, ons, concepts, data descriptions or other fort of representation intended to express beliefs, judgments, experiences, reasons, information or opinions. The ability of critical analysis in this study is the ability of students to decipher information into smaller parts so that deper meaning can be obtained through several indicators that is: (1) organizing. (2) linking parts or variables in that information; (3) interpreting data; (4) evaluating of informing: (5) reflecting for to the concepts and problem solving that are on making is a component of critical analysis evaluating activities, students will be able to creative thinking process; so that it is abl, and formulated (Facione, 1990)

The learning process in higher education which focuses on transferring information becomes an important supporting factor for developing dispositions, critical thinking skills, and critical analysis of students. Knowledge that has characteristics that can be justified, true, and can be trusted (Brookhart, 2010) is indeed relevant to be taught through thinking skills including critical thinking and critical analysis. $\mathrm{Cr}$ tical thinking and critical analysis have become an important part of learning objectives that must be achieved at the tertiary level in Indonesia, as stated in Permendikbud No. 73 of 2013 concerning the Indonesian National Qualifications Framework (IQF/KKNI). The excerpt in KKNI level 6 qualification levels is stated that students must be able to formulate procedural problem solving, make appropriate decisions based on information analysis, and provide guidance in choosing various alternative solutions. The study of several theories shows that the as pects of competency that must be achieved by students in the IQF are important aspects in critical thinking and critical analysis. The objectives in the IQF are in accordance with indicators of critical thinking disposition, critical thinking skills, and critical analysis according to experts, that is the process of solving problems (Mitrevski \& Zajkov, 2011), making the right decisions (Rudinow \& Barry,2007; Paul \& Elder , 2019; Fisher, 2011; Ennis, 1996), and analyzing information (Facione, 2007; Kiltz, 2009; Ennis, 1996) and consciously (reflective) choosing various alternative solutions (Ennis, 1996; Lai et al., 2015; Cropley, 2015; Bakir \& Oztekin, 2014; Ceran et al., 2014).

Gender is one of the factors that can influence one's thinking skills (Aliakbari \& Sadeghdaghighi, 2011; Harish, 2013; Mahanal et al, 2017). Gender is a general term that refers to male and female (Fin \& Ishak, 2012; Mahanal et al, 2017) that shape psychology and one's social role (Fuad, et al., 2017) so that it afects how individuals think, behave, and feet a phenomenon within themselves (Santrock, king skills based on gender were cond thinRuff (2005) who measured conducted by Ruff (2005) who measured critical thinking skills and critical thinking disposition using Test) and CCTDI (Califoriting Disposition Inventory) developed by Facione (2007) found that female students at critical thinking skills than there were no differences in the critical thinking disposition between female and male students. On the other hand, Dagun (1992) stated that male and female can differ in the context of hinking and disposition skills in which male tend to think more analytically and flexibly than emale, while female are less capable of abstract and logical thinking (Krutetskiī, 1976). Male and female have no difference in understanding concepts, but male are superior in probem solving than female (Gok, 2014). Teghva al. (2014) stated that there was no significant critcal thinking correlation between male and ferie that (he female prospective teacher was better than male in composite inquisitiveness and maturity, while male were better on self-confidence an openthe (2014) foun that king disposition is significantly different between male and female in inquisitiveness an systems. Mutakinati et al (2018) found that the skidents critical thinking skill was categorized as advanced thinker. $41.6 \%$, practicing thinker: $30.6 \%$, beginning thinker: $25 \%$, and challenged thite category for students critical therer in general but checific classification regarding the This

This study is important to conduct be cause differences in thinking skills caused by gender have been extensively studied but none have been specific to the prospective teachers critical thinking skills (critical thinking components) and critical analysis. This study aims to identify the critical thinking skills of prospective teacher students consisting of 6 (six) components that are: (1) interpretation; (2) analysis (3) inference; (4) evaluation; (5) explanation, and (6) self-regulation; and critical analysis skills of prospective teachers consisting of 6 (six) components that are: (1) organizing; (2) linking parts or variables in the information (as sociation); (3) interpretation of data; (4) evalu(6) of information; (5) reflection process; and (6) make decisions that are relevant to the conThe results of the study that are formulated. ding to and female gender and were expected to be able to provide a skills, and critical analysis of prospective biology teachers based on gender to be considered in choosing strategies, approaches, and a more effective learning model for teaching thinking skills and dispositions. 


\section{METHODS}

The instrument developed was also tested

This is a descriptive quantitative study on 20 biology students who had taken anatomy with survey methods to explore prospective validity and reliability of the tests developed. teachers' critical thinking and critical analysis The results of the instrument trials were then skills of 100 biology procpective teachers $(50$ analyzed to determine the validity and interpremales and 50 females) who take the anatomy tation of the instrument. The results of testing and plant development courses selected using the validity and reliability of the instruments purposive random sampling (Fraenkel et al., developed are presented in Table 3 and Table 2011). Twelve item test descriptions on plant anatomy and development material were used to collect data on critical thinking skills and critical analysis of prospective teacher students. Descriptive tests developed to collect data on critical thinking skills are prepared based on six indicators of critical thinking skills by Facion (1990) and six indicators of critical analysis in the study, namely: (1) organizing; (2) associations; (3) interpretation; (4) evaluation; (5) reflection; and (6) make a decision.

The instrument of critical thinking skills was developed in accordance with the indicators of critical thinking skills in the anatomy and development of plants. The instrument developed was then assessed for content and construct validity by 2 experts categorized in Table 1 .

Table 1. The Category of Instrument Validity Based on the Average Value of the Validator

\begin{tabular}{cc}
\hline Score Interval & Category \\
\hline$>3.6$ & Very valid \\
$2.8-3.6$ & Valid \\
$1.9-2.7$ & Invalid \\
$1.0-1.8$ & Not Very Valid
\end{tabular}

Adapted from Ratumanan and Laurens (2011).

Instrument reliability was analyzed using equations: Percentage of agreement $=100[1-(A B)$ $/(A+B)]$ (Emmer \& Millett in Borich, 1994),
where $\mathrm{A}$ is the frequency of behavioral aspects where $A$ is the frequency of behavioral aspects observed by the observer giving a high frequen $c y$, and $B$ are the frequency of behavior aspects observed by other observers by providing a low
frequency. The instruments are declared reliable if the reliability score is $\geq 75 \%$. The results of if the reliability score is $\geq 75 \%$. The results of
testing the validity and reliability of the instruments developed based on content and construct validity are presented in Table 2 below.

Table 2. The Content and Construct Validity and 2 Reliability of Instruments

\begin{tabular}{ccccc}
\hline $\mathbf{N}$ & $\begin{array}{c}\text { Content } \\
\text { validity }\end{array}$ & $\begin{array}{c}\text { Reliabil- } \\
\text { ity }\end{array}$ & $\begin{array}{c}\text { Construct } \\
\text { validity }\end{array}$ & $\begin{array}{c}\text { Reliabil- } \\
\text { ity }\end{array}$ \\
\hline 12 & 3.83 & 0.97 & 3.87 & 0.98 \\
\hline
\end{tabular}

4 below.

Table 3. Results of Instrument Validity Test

\begin{tabular}{cccc} 
Items & $\begin{array}{c}\text { Pearson } \\
\text { Correlation }\end{array}$ & $\begin{array}{c}\text { Sig. } \\
\text { (2-tailed) }\end{array}$ & Remarks \\
\hline Number 1 & .598 & .005 & Valid \\
Number 2 & .354 & .126 & Invalid \\
Number 3 & .682 & .001 & Valid \\
Number 4 & .369 & .110 & Invalid \\
Number 5 & .661 & .002 & Valid \\
Number 6 & .165 & .486 & Invalid \\
Number 7 & .550 & .012 & Valid \\
Number 8 & .357 & .123 & Invalid \\
Number 9 & .431 & .058 & Invalid \\
Number 10 & .374 & .105 & Invalid \\
Number 11 & .737 & .000 & Valid \\
Number 12 & .338 & .145 & Invalid \\
\hline
\end{tabular}

\section{Table 4. Reliability Instruments}

\begin{tabular}{cc} 
Cronbach's Alpha & N of Items \\
\hline .703 & 12
\end{tabular}

Based on the test results, it is found that reliable instruments are used to collect data on presented two examples of the intended essay test items.

1. If you observe plants in the surrounding environment, you might see a variety of colors of tion of organelles found in the cells meing tion of organelles found in the cells making up these organs, why do flower and fruit organ 2. One of the fus? a role in the functions of vacuole is to play a role in cell growh, how do you explain the function of the vacuole?

Respondents answers were then analycritical analysis al thinking skills rubric an crict previously been developed by Fabric that (1994) with scores of 1 to 4 as shown in Table 5. critical thinking skills and critical analysis of prospective biology teachers in anatomical and plant development material. The following are
Table 5. The Critical Thinking Skills Rubric

\begin{tabular}{|c|c|c|}
\hline Indicators & Score & Description \\
\hline \multirow{4}{*}{ Interpretation } & 4 & $\begin{array}{l}\text { Students are able to interpret the problems given by describing the relationship be } \\
\text { tween relevant variables precisely (sharply). }\end{array}$ \\
\hline & 3 & $\begin{array}{l}\text { Students are able to interpret the problems given by describing the relationship be- } \\
\text { tween the relevant variables but still not precise or lacking precision. }\end{array}$ \\
\hline & 2 & $\begin{array}{l}\text { Students are able to interpret the problems given but are less relevant to the variables } \\
\text { contained in the problem. }\end{array}$ \\
\hline & 1 & Not able to interpret the problem given \\
\hline \multirow{4}{*}{ Analysis } & 4 & $\begin{array}{l}\text { Given a phenomenon or data then students are able to provide the right arguments } \\
\text { and are based on the analysis in accordance with the concept. }\end{array}$ \\
\hline & 3 & $\begin{array}{l}\text { Students are able to provide the right argument but are based on analysis that is not } \\
\text { in accordance with the concept. }\end{array}$ \\
\hline & 2 & $\begin{array}{l}\text { The arguments conveyed were quite good but were unable to provide reasons that } \\
\text { were in accordance with the correct concept. }\end{array}$ \\
\hline & 1 & Cannot analyze claims, facts or arguments. \\
\hline \multirow{4}{*}{ Evaluation } & 4 & $\begin{array}{l}\text { Significance or assumptions are given then students are able to provide precise predic- } \\
\text { tions and evaluate these predictions based on variables that are in accordance with the } \\
\text { correct and precise concepts. }\end{array}$ \\
\hline & 3 & $\begin{array}{l}\text { Learners are able to provide the right predictions and evaluate these predictions based } \\
\text { on the analysis in accordance with the concept, but the analysis given is less precise. }\end{array}$ \\
\hline & 2 & $\begin{array}{l}\text { Students are able to provide precise predictions but cannot provide appropriate evalu } \\
\text { ations based on the correct analysis and according to the concept. }\end{array}$ \\
\hline & 1 & Students are able to provide predictions and evaluate these predictions. \\
\hline \multirow{4}{*}{ Inference } & 4 & $\begin{array}{l}\text { Given a number of data, graphics or images, students are able to make precise pre- } \\
\text { dictions and formulate or make inferences correctly based on predictions, data, and } \\
\text { graphics or images that are presented based on the correct concept. }\end{array}$ \\
\hline & 3 & $\begin{array}{l}\text { Students can make the right predictions but are less precise in formulating or making } \\
\text { inferences based on data, graphics or images provided. }\end{array}$ \\
\hline & 2 & $\begin{array}{l}\text { Students are able to make precise predictions but are unable to formulate or make } \\
\text { inferences according to the data, graphics or images presented. }\end{array}$ \\
\hline & 1 & Not able to make inference \\
\hline \multirow{4}{*}{ Explanation } & 4 & $\begin{array}{l}\text { Phenomena or assumptions are given then students are able to make statements and } \\
\text { provide explanations based on the correct concepts. }\end{array}$ \\
\hline & 3 & $\begin{array}{l}\text { Give an explanation based on the correct concept, but cannot make a statement or } \\
\text { statement contrary to the explanation given. }\end{array}$ \\
\hline & 2 & Able to make statements, but less relevant to the correct concept. \\
\hline & 1 & Unable to give statements and explanations \\
\hline \multirow{4}{*}{$\begin{array}{l}\text { Self-regula- } \\
\text { tion }\end{array}$} & 4 & $\begin{array}{l}\text { The phenomenon or assumptions are given then students are able to explain the } \\
\text { causes of the event can occur based on the knowledge they know and explain the } \\
\text { relevance of their explanations to the concepts/laws/principles that are correct. }\end{array}$ \\
\hline & 3 & $\begin{array}{l}\text { Explaining the causes of these events can occur based on the knowledge they know } \\
\text { but are less precise in explaining the relevance of their explanations to the correct } \\
\text { concepts/laws/principles. }\end{array}$ \\
\hline & 2 & $\begin{array}{l}\text { Explaining the causes of these events can occur based on the knowledge they know } \\
\text { but cannot explain the relevance of their explanation to the correct concept / law } \\
\text { principle. }\end{array}$ \\
\hline & 1 & Unable to regulate their knowledge. \\
\hline
\end{tabular}

Respondents' answers were then analyzed scores of 1 to 4 . The results of analysis of critical using the critical thinking skills rubric and criti- thinking skills and critical analysis were then cacal analysis adapted from the rubric that had pre- tegorized by categories in Table 6 .

viously been developed by Facione (2007) with 
Table 6. The Criteria of Levels of Critical Think- analysis include the results of the identification ing and Critical Analysis of differences in each component of the variables Score and the correlation between the variables in this $\begin{array}{ccc}\text { Criteria } & \text { Score } & \text { study. } \\ \text { Not yet visible or still underde- } & 1-2 & \end{array}$

veloped

Start developing or developing $3-4$ well

\section{RESULTS AND DISCUSSION}

The critical thinking skills and critical anaThe variables in this study were analyzed be developed further. The complete results are using IBM SPSS 23 software. The results of the presented in Table 7 below.

Table 7. Critical Thinking Skills and Critical Analysis of Prospective Teacher as a Whole

\begin{tabular}{cccccc}
\hline Criteria & Score & Gender & $\begin{array}{c}\text { Number of } \\
\text { Students }\end{array}$ & Percentage & $\begin{array}{c}\text { Total } \\
\text { Percentage }\end{array}$ \\
\hline $\begin{array}{c}\text { Not yet visible or still } \\
\text { underdeveloped }\end{array}$ & $1-2$ & Male & 50 & $78 \%$ & $81 \%$ \\
Start developing or devel- & \multirow{2}{*}{$3-4$} & Female & 50 & $84 \%$ & \\
oping well & Male & 50 & $22 \%$ & $19 \%$ \\
\hline
\end{tabular}

Table 7 shows that $81 \%$ f prosective bio- lysis, evaluation, and logy teachers of FPMIPA IKIP Mataram have regulation (Facione, 1990). The results of the critical thinking skills and critical analysis with respondent's answers were then analyzed using criteria that have not yet appeared or are still un- rubric critical thinking skills based on 6 (six) indiderdeveloped, while only $19 \%$ are categorized as cators of critical thinking skills as described eardeveloping or developing well. The results of cri- lier. The results were then analyzed statistically tical thinking skills and critical analysis of male using the $U$ (Mann-Whitney Test) test because and female biology teacher students are presented the results of the test of distribution of data on in Table 8 below.

Table 8. Independent Sample Test of Critical Thinking Skills and Critical Analysis of Male and Female Biology Teacher Candidates

\begin{tabular}{llllll}
\hline Variables & Gender & $\mathbf{N}$ & Mean & $\boldsymbol{\Sigma} \mathbf{N}$ & $\mathbf{p}$ \\
\hline
\end{tabular} $\begin{array}{llllll}\text { Critical } & \text { Male } & 50 & 46.6670 & 100 & .359 \\ \text { Thinking } & \text { Female } & 50 & 48.1672 & & \end{array}$

Thinking Female $50 \quad 48.1672$

$\begin{array}{llllll}\text { Critical } & \text { Male } & 50 & 55.1940 & 100 & .319\end{array}$

Female biology prospective teachers have better critical thinking skills (mean: 46.1672) than male (mean: 46.6670), while male students have better critical analysis skills (mean: 55.1940 ) than female (mean: 53.5580), yet critical thinking skill (p: .359) and critical analysis (p: .19) of students of male and female prospective teachers are not significantly different. The following are the results of the study in full with different indicator of critical thinking skills and critical analysis of
prospective biology teacher students in terms of gender.

\section{Critical Thinking Skill}

Critical thinking skills of prospective tetions with characteristics of interpretation, anacrical hinking skills of prospective teacher were do normally distributed. The test ains of students' critical thinking skills as presented in Table 9.

Table 9. The Results of U Test for Critical Thinking Skills of Prospective Teachers.

\section{Mann-Whitney Test}

$\begin{array}{lccccc}\text { Component } & \begin{array}{c}\text { Gen- } \\ \text { der }\end{array} & \text { N } & \text { Mean } & \mathbf{\Sigma} N & \mathbf{p}\end{array}$

\begin{tabular}{llllll} 
Interpretation & Male & 50 & 59.81 & \multirow{2}{*}{100} & .001
\end{tabular}

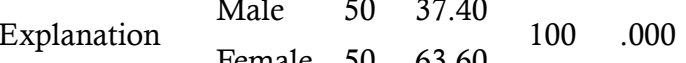

$\begin{array}{llllll}\text { Regulation } & \text { Female } & 50 & 59.91 & 100 & .000\end{array}$

Table 9 shows that the components of students' critical thinking skills differ in 1) the interpretation in which male are better at interpreting the problem given (mean $=59.81$ ) than female (mean $=41.19) ; 2$ ) explanation, female prospective teacher are better at explanation (mean 63.60) than male (mean = 37.40); and 3) selfteachers are also better at solving problems that require respondents to regulate their knowledge acher candidates $($ mean $=41.09)$.

\section{Critical Analysis}

The results of critical analysis skills of prospective students were analyzed statistically using the U (Mann-Whitney Test) test because the results of the test of data distribution of critical analysis abilities of prospective teachers were declared not to be normally distributed. The test aims to determine the differences in the components of critical analysis abilities of prospective teachers as presented in Table 10.

Table 10. The Results of U-Test Critical Analysi of Prospective Teacher

\begin{tabular}{cccccc}
\hline \multicolumn{6}{c}{ Mann-Whitney Test } \\
\hline Component & Gender & $\mathbf{N}$ & Mean & $\mathbf{\Sigma N}$ & $\mathbf{p}$ \\
\hline Interpreta- & Male & 50 & 66.14 & \multirow{2}{*}{100} & \multirow{2}{*}{000} \\
tion & Female & 50 & 34.86 & & \\
\multirow{2}{*}{ Explanation } & Male & 50 & 39.46 & \multirow{2}{*}{100} & .000 \\
& Female & 50 & 61.54 & & \\
\hline
\end{tabular}

Based on Table 10, the critical analysis ability of female prospective teachers is better (mean $=61.51)$ than male $($ mean $=39.46)$ on explanatory components, while male prospective teachers are better (mean $=66.14$ ) than female (mean $=34.86$ ) in the interpretation component. This result is in line with the same component of critical thinking skills where male are better than female in the interpretation componen and female are better than male in the explanatory component.

The results show that critical thinking skills and critical analysis of prospective teachers still need to be developed, but the correlation between critical thinking skills and critical analysis of prospective teacher shows a positive correlation between the two components as presented in Table 11, so it is important to teach critical thinking skills and critical analysis comprehensively.

Table 11. Correlation of Critical Thinking Skill and Critical Analysis of Prospective Teachers

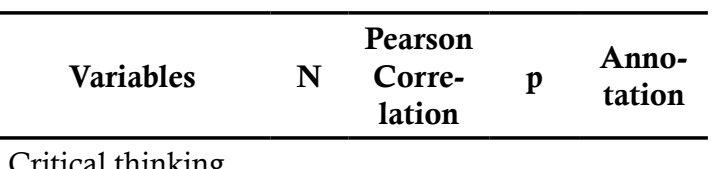

Critical thinking
skills (CT)

$\begin{array}{lllll}\text { skills (CT) } & 100 & .685 & .923 & 100^{\text {crCA }}\end{array}$

(923)
Critical Thinking Skills and Critical Analysis

Critical thinking skills and critical analysis of biology teacher candidates in general are declared not yet visible or still underdeveloped ( $\mathrm{sco}^{-}$ re 1-2) with a percentage of $81 \%$. The response shown based on student answers shows the lack of student interpretation and explanation skills towards the phenomena presented in the test instruments given. The implication of these results is the teachers' low skills on critical thinking indicators and other critical analyzes. Critica hinking and critical analysis are essentially reflective thinking processes (Dewey, 1933; Ennis, 1996; Facione, 1990) which are human activitie in looking back on their experiences, thinkin about those experiences, considering and evaluating them (Loughran, 2002) where activity these activities are interconnected (Ennis, 2011; Facione, 2007; Rudinow \& Barry, 2007)

The weakness of critical thinking skills an critical analysis of students is indicated by the inability to show good interpretation, explanation, and self regulation. The statement was based on students' response to problem number 1. FM student state that flower and fruit organs have varying colors because the flower and fruit organs are influenced by certain hormones, this results in different color and fruit organs. Other students wrote a response similar to the response written by FM students that $t h$ flowers and fruit experience segmentation where this segment affects the color of the flower and fruit. Some students wrote the response that color difference in fruits and leaves were caused by plants having chloroplasts, while kroroplast functioned when plants carried out photosynthesis, for example A several types of color pigments such in which there are etc. these pigments pausen various as chocolate, blue, exist in fruit leaves and stems because cof colors that found in all parts plant. Similar response with aI ond have varying colors because there are chlorophy flowers roplasts in the cells making up these organs.

Student responses indicate that critical thinking skills and critical analysis of students are det is more likely to be doubtful and no prehensive. Students fail to consider the possibilty of color variants giving fruit and flowers such as chromoplast and leukoplas found in plats such Cell organelles that have one of the functions as ploce for storing color pigme the functions as a fail to be considered by students as a possible solution to the problem given. 
Critical thinking skills and critical analysis pretation, explanation, and self-regulation, wheof students as much as $18 \%$ are categorized as re female students are better at explanation and developing or developing well. Student responses self-regulation components, while male students indicate the construction of arguments supported are better at the interpretation component. These by general concepts, although not yet detailed. Tesults are in line with the results of critical anaStudents must be able to make arguments based lysis, female students are better at the explanation the theory of problem solving (Vargas Alfon- on component, while male students are better at so, 2015). Self-regulation is important in this si- the interpretation component. In general, female tuation to manage thoughts, feelings, and actions students have critical thinking skills better than based on plans (Zimmerman \& Schunk, 2001) to male students, while male students have critica regulate cognition strategies (Asy'ari \& Ikhsan., analytical skills better than female. The results 2019)so that students can analyze the problem of this study are in line with the statements of \& Eslamdoost, 2014)

On the other hand, OAH and TW student thinking skills are better than male. Female stuwho have critical thinking skills and critical ana- dents are more precise, thorough, and logical in lysis that are beginning to develop gave an answer asking questions than male students Crawford et that had a similar concept but was not elaborated in detail i.e. the color varies in flowers and fruit depen ding on the plastids found in the plant, because each plant has a different colour level with different levels of colour requirements. Plant cell organelles found in plastids such as chloroplast, leucoplast, and chromoplast, cause fruits and flowers to have different colours.

Two examples of student responses indicate that some students begin to develop critical thinking skills and critical analysis. The response can be categorized as constructed based on a concept that is relevant to the problem given. The development of critical thinking skills and critical
analysis of students can be facilitated through the provision of routine problems, linking new knowledge (Thompson, 2011) so as to help students make decisions for what is done and trusted (Ennis, 1996).

High-level thinking skills including critica thinking and critical analysis are mental habits that require students to think about their thinking and around to improve the process, requiring students to use high-level thinking skills, not memorizing data or accepting what they read or being told without thinking about it so that thinking dispositions are important also to be explicitly taught in the learning process (Ennis, 1996; Facione, 2007). Furthermore, Alper (2010) stated that there is a significant difference between someone who has good critical thinking skills and someone who fails critical thinking related to choosing, organizing, and using data. The teacher plays an dents (Demirhan \& Köklükaya, 2014).

Critical Thinking Skills and Critical Analysis

\section{of Male and Female Students} (Fuad et al, 2017). Table 8, Table 9, and Table 10 show the critical thinking skills of differen prospective students in the components of inter-
The results of the study show that critiand women are not significantly different. The se results are supported by the results of Yanice (2012) research; Kucuk \& Uzun (2013); Tumkaya (2011); Alper (2010);Salahshoor and Rafie difference between critical thinking skills of male and women. Different results were conveyed by Bezci \& Sungur Vural (2013) that the learning outcomes of female students were better than male. This result might occur considering the restudents were better at processing textual information. This phenomenon is influenced by initi knowledge as a person's basic capital in critical thinking (Fuad et al, 2017).

The description of the results indicates that it is important to teach critical thinking skills and critical analysis of prospective teachers given the many positive implications that can be attributed to critical thinking skills and critical analysis towards learning outcomes and the construction of we of 21 century. The opinion was supported by

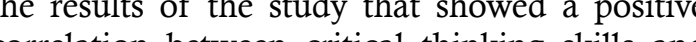
critical an between critical thinking skills and aya (2011) research found a positive corro, Tumbetween critical thinking skills and learning outcomes.

Improving Critical Thinking Skills and Critical alysis through Innovative Learning

When developing thinking dispositions, thinking skills, and critical analysis are the focus of the learning process, students must be given freedom (and responsibility) to explore content, analyze resources, and apply information. thinking skills and critical analysis of male (2016) which states that there is no significan with the results of prospective teachers. In line
Although some students may be naturally curious, training is needed that is systematically anacan become self-confident in their reasoning and apply critical thinking skills and their critical analysis to each area of content or discipline (Peter, 2012).

High-level thinking skills including critica thinking and critical analysis are often associated with scientific methods which are systematic and procedural approaches to thought processes ( $\mathrm{Sc}-$ riven \& Paul, 2007). Scientific methods or scientific skills are often termed science process skills that are believed to be the basis for gaining knowledge and developing life skills including thinking skills (Nur, 2011) and critical analysis (Mishra \& Kereluik, 2011; Muhali, 2018). In line with this opinion, Ibrahim et al. (2010) stated that process skills can bridge a person to independent learning, self-development and lifelong learning.

The application of a systematic approach such as process skills does not guarantee the achievement of the development of thinking dispositions, critical thinking skills, and good critical analysis for students. These results are also proven empirically from the results of study that show that critical thinking skills and critical analysis are generally categorized as not yet visible or still underdeveloped (score 1-2) so that teaching books as supporting learning need to be provided properly. Textbooks as a supporter of the effectiveness of learning support competency and ef fective communication in each model innovatio and learning strategy.

Textbooks are compiled but not in accordance with the characteristics of teaching material and the learning model tends to have an impact on biased and undirected learning so that the general goal of education is to optimize the skills of learners (Dancy et al., 2016). Knowledge in textbooks has characteristics that can be justified, true, and can be trusted (Brookhart, 2010) is very relevant to be learned through process skills. The science process skills are believed to be the basis for gaining knowledge and developing life skils (Nur, 2011). One life skill that needs to be coveloped though the education process and beis thinking skills (Mishra \& Kereluik, 2011) such is thinking skills (Mishra \& Kereluik, 2011) such dispositions (Thomas, 2012; Zohar, 2012; Wasis, 2016).

In addition, the material contained in texning and improving the quality of learning must be supported by actions or activities carried out by students, because the presentation of knowledge is not enough, presentation of material must be combined with a process skills approach (Kuria \& Fathurrohman, 2014), as a basis for gaining knowledge and developing high-level thinking (Adisendjaja \& Romlah, 2007; Asy'ari \& dently, develop themselves and lifelong learnin (Ibrahim et al., 2010).

Critical thinking and critical analysis are the domains of high-level thinking, where highlevel thinking can and should be taught (Woolfolk, 2012) persistently and continuously and thoroughly (Fisher, 2011), and can be trained with simple learning patterns Eggen \& Kauchak, 2012) and by choosing the right learning strategy. Critical thinking can be trained through inquiry activities (Arends \& Castle 1991; Fuad et al, 2017) by questioning what is seen and heard. Critical thinking requires students to actively and skillfully conceptualize, apply, analyze, synthesize, and or evaluate information collected or generated from observation, experience, reflection, communication reasoning, or as a guide to beliefs and action (Mitrevski \& Zajkov; 2011) not only absorb ideas from teachers (Lunenburg, 2011). The results of the Prayogi \& Asy'ari (2013) study stated that those students' critical thinking skills can be improved through the application of problem-based learning models, because in learning students are required to solve the problems posed to actively practice their thinking skills. Fink (2003) showed that students learn more and maintain knowledge onger if they get it actively rather than passively. Integration of science process skills in teaching materials can help students make simple observations/experiments, discoveries, problem analysis, problem solving, and communication of understerial can be understood concretely and comprehensively by of Madsen et al. (2016) that textbooks con principles of experim and problem solving including science process kills, in addition to being a learning nece also a student guide to linking procedurl fact l, and conceptual and metacognition of stuctuinterests and talents.

\section{CONCLUSION}

This study has achieved its objectives. The study aims to explore prospective teachers' critgender. The results of the study show based on prospective teachers' critical thinking and cri- 
tical analysis skills differ in several components although overall there is no significant difference critical thinking and critical analysis skills. The results of the study also showed a positive correlation between critical thinking skills, and critical analysis of prospective teachers. The prospective teachers' critical thinking and critical analysis skills still need to be developed.

The need for specific supporting teaching materials as structured and detailed learning guidelines for furniture teaching critical thinking skills and critical analysis of students so that the goal of developing high-level thinking skills can be achieved. These findings contribute as lecturers' references in teaching critical thinking skills and critical analysis of prospective teachers in learning by paying attention to differences in skills based on prospective teachers' gender.

The results of this study are limited to the investigation of critical thinking skills and critical analysis of prospective biology teacher FPMIPA IKIP Mataram in the anatomy and developmen of plants. The results of this study can be used as a basis for further discussion and research in the context of other high-level thinking skills such as creative thinking, problem solving, and metacognition

\section{ACKNOWLEDGMENTS}

We would like to thank to Ministry of Research, Technology and Higher Education of the Republic of Indonesia who have provided funding support in the completion of this study (Decree number: 3/E/KPT/2018).

\section{REFERENCES}

Adisendjaja, Y. H., \& Romlah, O. (2007). Analisis Buku Ajar Sains Berdasarkan Literasi Ilmiah Sebagai Dasar untuk Memilih Buku Ajar Sains
(Biologi). In Disampaikan dalam Seminar Pendidikan Nasional di Jurusan Pendidikan Biologi FMIPA (pp. 25-26).

Alper, A. (2010). Critical Thinking Disposition of PreService Teachers. Egitim ve Bilim, 35(158), 14

Vargas Alfonso, D. (2015). Evidence of Critical Thinking in High School Humanities Class-
rooms. Gist-Education and Learning Research rooms. Gist-Education

Aliakbari, M., \& Sadeghdaghighi, A. (2011, August) der, Field of Study, and Critical Thinking Skill: The Case of Iranian Students. In The 16th Con ference of Pan-Pcific Association of Applied Linguistics, The Chinese University of Hong Kong.
a Tax onomy for Learning, Teaching, and Assessing: A
Revision of Bloom's Taxonomy of Educational Objectives. Longman.

Arends, R., \& Castle, S. (1991). Learning to Teach (Vol 2). New York: McGraw-Hil.

'ari, M., \& Ikhsan, M. (2019). The Effectiveness of Inquiry Learning Model in Improving Prospec-
tive Teachers' Metacognition Knowledge and tive Teachers' Metacognition Knowledge and of Instruction, 12(2), 455-470.

Asy'ari, M., \& Fitriani, H. (2017). Literatur Reviu Keterampilan Proses Sains sebagai Dasar Pengembangan Keterampilan Berpikir Tingkat Tinggi. Prisma Sains. Jumal Pengkajian Ilmu da ram, 5(1), 1-7.

Bakır, S., \& Öztekin, E. (2014). Creative Thinking Levels of Preservice Science Teachers in Terms of Different Variables. Journal of Baltic Science Edu

cation, 13(2), 231-242.
Bezci, F., \& Sungur Vural, S. (2013). Academic Procrastination and Gender as Predictors of Science Achievement. Journal of Educational \& In art, S. M. (2010).

How to Assess Higher-Order Thinking Skills in Your Classroom. ASCD.

, S. A., Güngören, S. C., \& Boyacioğlu, N. (2014). Determination of Scientific Creativity Levels of Middle School Students and Perceptions Through Their Teachers. European Journal
of Research on Education, 47-53.

Crawford, A., Saul, W., \& Mathews, S. R. (2005). Teaching and Learning Strategies for the Thinking Classroom. IDEA.

Cropley, D. H. (2015). Promoting Creativity and Innovation in Engineering Education. Psychology of

Aesthetics, Creativity, and the Arts, $9(2), 161$.
Dagun, S. M. (1992). Maskulin dan Feminin: Perbedaa Pria-Wanita dalam Fisiologi, Psikologi, Seksual, Karier, dan Masa Depan. Rineka Cipta.

en, C. (2016). How Faculty Learn about and Implement ResearchBased Instructional Strategies: The Case of Peer Instruction. Physical Re
tion Research, 12(1), 010110 .

a, A. N. (2014). The Critical Thinking Dispositions of Prospective Science Teachers. Procedia-Social and Behavioral Sciences, 116, 1551-1555.

Relation of Reflective Thin: A Restatement of the Rrocess. DC Reath.

Eggen, P., \& Kauchak, D. (2012). Strategi dan Model Pembelajaran. Jakarta: Indeks.

Ennis, R. H. (1996). Critical Thinking Dispositions Their Nature and Assessability. Informal Log $i c, 18(2)$

Ennis, R. H. (2011). The Nature of Critical Thinking
Facione, P. A. (2007). Critical Thinking: What It is and Why It Counts. 2010 Update. Millbrae, CA:Cali

Facione, P. (1990). Critical Thinking: A Statement of Expert Consensus for Purposes of Educational (The Delphi Report)

Facione, N. C., Facione, P. A., \& Sanchez, C. A. sure of Critical Thinking Disposition as a Meavelopment of the California Critical Thinking Disposition Inventory. Journal of Nursing Education, 33(8), 345-350.

Fahim, M., \& Eslamdoost, S. (2014). Critical Thinking rrameworks and Models for Teaching. English

in, L. S., \& Ishak, Z (2012). A Priori dents' Academic Achievement: The Effect of Gender as Moderator. Procedia-Social and Behavioral Sciences, 65, 1092-1100.

Fink, L. D. (2003). A Self-Directed Guide to Designing Courses for Significant Learning. University of Oklahoma, 27(11).

Fisher, A. (2011). Critical Thinking: An Introduction Cambridge University Press.

Fitriani, $\mathrm{H}$, Asy'ari, M , Zubaidah, S. \& Mahanal, S. (2018, November). Critical Thinking Disposition of Prospective Science Teachers at IKIP Mataram, Indonesia. In Journal of Physics: Conference Series (Vol. 1108, No. 1, p. 012091). IOP Publishing.

Fraenkel, J. R., Wallen, N. E., \& Hyun, H. H (2011). How to Design and Evaluate Research i ties/Social Sciences/Languages.

Fuad, N. M., Zubaidah, S., Mahanal, S., \& Suarsini, E. (2017). Improving Junior High Schools' Critical Thinking Skills Based on Test Three Different Models of Learning. International Journal of

Gok, T. (2014). Peer Instruction in the Physics Class Room: Effects on Gender Difference Per lem Solving Journal of Baltic Science Educa tion, $13(6)$.

Harish, G. C. (2013). Critical Thinking Skills among Ninth Standard Students in Relation to Gender, Intelligence and Study Habits. International
Journal of Education and Psychological Research (IJEPR), 2(3), 13-20.

Dias, M. (2013). The Art of Teaching Science: Inquiry and Innovation in Middle School and

Ibrahim, M., Nur, M., \& Kasdi, A. (2010). DasarDasar Proses Belajar Mengajar. Surabaya: Un press . (2009). Developing Critical Thinking Skills in Homeland Security and Emergency Management Courses. Joumal of Howend Security and Emergency Management, 6(1).
(1) V. A., WIRSZUP, I.

P, I., \& Kilpatrick, (1976). The Psychology of Mathematical Abilities in School Children. University of Chicago Press. D. P., \& Uzun, Y. B. (2013). Critical Thinkin Tendencies of Music Teacher Candidates. Jou nal of Kirsehir Education Faculty, 14(1), 327-345. nia, F., \& Fathurohman, A. (2014). Analisis Bahan Ajar Fisika SMA Kelas XI di Kecamatan
Indralaya Utara berdasarkan Kategori Literasi Sains. Jurnal Inovasi dan Pembelajaran Fisi$k a, 1(1), 43-47$.

Lai, C. F., Hwang, R. H., Chen, S. Y., Huang, H. M. \& Wu, T. T. (2015, January). Influence of Integrating Creative Thinking Teaching into Project-based Learning Courses to Engineering College Students. In 43rd SEFT Annual Confer gineering Education (SEFI). M. (1987). Critical Thin Be?. Analytic Teaching, 8(1)

Learning about Teaching and Learning through
Levelong Reflive Practice Modelling. Routledge.

nenburg, F. C. (2011). Critical Thinking and Constructivism Techniques for Improving Studen Achievement. In National Forum of Teacher
cation Journal (Vol. 21, No. 3, pp. 1-9).

Madsen, A., McKagan, S. B., Martinuk, M. S., Bell, A., \& Sayre, E. C. (2016). Based Assessment Affordances and Constraints: Perceptions of
Physics Faculty. Physical Review Physics Education Research, 12(1), 010115.

Mahanal, S. (2012). Strategi Pembelajaran Biologi, Gender dan Pengaruhnya terhadap Kemam-
puan Berpikir Kritis. In Seminar Nasional VII Pendidiken Biologi (Vol 9, No 1, pp. 179-184).

Mahanal, S. Tendrita, M. Ramadhan, F, Ismirawati, N., \& Zubaidah, S. (2017). The Analysis of Students' Critical Thinking Skills on Biology Subject. Anatolian Journal of Instruction, 2(2), 21-39. hra, P., \& Kereluik, K. (2011, March). What 21s Century Learning? A Review and a Synthesis Ed Society for Informanion Technology \& Teacher 3312). Association for the Advancement of Computing in Education (AACE).

Mitrevski, B., \& Zajkov, O. (2011). Mathematics and Science Teachers' Concept
ing. Bulg. J. Phys, 38, 318-32 tional Analysis of EFL University Students Critical Thinking and Self-Efficacy. Journal $O f$

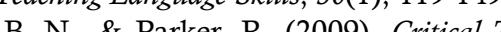
Boston, MA: McGraw-Hill.

Muhali, M. (2018, September). Arah Pengembanga Pendidikan Masa Kini Menurut Perspektif Revolusi Industri 4.0. In Prosiding Seminar $\mathrm{Na}$ sional Lembaga Penelitian dan Pendidikan ( $L P P)$

Mandala.
utakinati, L., Anwari, I., \& Kumano, Y. (2018)
Analysis of Students' Critical Thinking Skill Analysis of Students' Critical Thinking Skil
of Middle School through STEM Educatio Project-Based Learning. Jurnal Pendidikan IPA

Krate

\begin{abstract}
An Outline of Critical Thinking Disposition
and Abilities. University of Illinois, 2-4.
\end{abstract}


Indonesia, 7(1), 54-65.

Nur, M. (2011). Modul Keterampilan-Keterampilan Proses Sains. Surabaya: Pusat Sains dan Matematika Sekolah Universitas Negeri Surabaya.

Paul, R., \& Elder, L. (2019). The Miniature Guide To Critical Thinking Concepts \& Tools. Rowman \& Littlefield.

Peter, E. E. (2012). Critical Thinking: Essence for Teaching Mathematics and Mathematics Problem Solving Skills. African Journal of Mathematics and Computer Science Research, 5(3), 39-43.

Prayogi, S., \& Asy'ari, M. (2013). Implementasi Model PBL (Problem Based Learning) untuk Meningkatkan Hasil Belajar dan Kemampuan Berpikir Kritis Siswa. Prisma Sains: Jurnal Pengkajian Ilmu dan Pembelajaran Matematika dan IPA IKIP Mataram, 1(1), 80-88.

Ratumanan \& Lauren. (2011). Evaluasi Hasil Belajar pada Tingkat satuan Pendidikan Edisi 2.

Reid, J. C. (2006). Mengajari Anak Berpikir Kreatif, Mandiri, Mental, dan Analitis. Terjemahan oleh Ahada Eriawan.

Rudinow, J., \& Barry, V. E. (2007). Invitation to Critical Thinking. Cengage Learning.

Ruff, L. G. (2005). The Development of Critical Thinking Skills and Dispositions in First-Year College Students: Infusing Critical Thinking Instruction into a First-Year Transitions Course (Doctoral dissertation).

Santrock, J. W. (2011). Life-Span Development 13th Edition. New York: Mcgraw-Hill. Schunk, Dh (2005). Self-Regulated Learning: The educational legacy of Paul R. Pintrich. Educational Psychologist, 40(2), 85-94.

Scriven, M., \& Paul, R. (2007). Defining Critical Thinking. The Critical Thinking Community: Foundation for Critical Thinking. Retrieved
July, 2, 2017.

Thomas, G. P. (2012). Metacognition in Science Education: Past, Present and Future Considerations. In Second International Handbook of Science Education (pp. 131-144). Springer, Dordrecht.

Thompson, C. (2011). Critical Thinking across the Curriculum: Process over Output. International Journal of Humanities and Social Science, 1(9), 1-7.

Tümkaya, S. (2011). Comparison of College Science Major Students' Learning Styles and Critical Thinking Disposition. Ahi Evran University Journal of Faculty of Education, 12(3), 215-234.

Woolfolk Hoy, A. (2012). Academic Optimism and Teacher Education. The Teacher Educator, 47(2), 91-100.

Yang, S. H. (2016). Conceptualizing Effective Feedback Practice through an Online Community of Inquiry. Computers \& Education, 94, 162-177.

Yenice, N. (2012, December). A Review on Learning Styles and Critically Thinking Disposition of Pre-Service Science Teachers in Terms of Miscellaneous Variables. In Asia-Pacific Forum on Science Learning and Teaching (Vol. 13, No. 2, pp. 1-31). The Education University of Hong Kong, Department of Science and Environmental Studies.

Zimmerman, B. J., \& Schunk, D. H. (Eds.). (2001). SelfRegulated Learning and Academic Achievement: Theoretical Perspectives. Routledge.

Zohar, A. (2012). Explicit Teaching of Metastrategic Knowledge: Definitions, Students' Learning, and Teachers' Professional Development. In Metacognition In Science Education (pp. 197223). Springer, Dordrecht. 